\title{
The real as problem in Fichte's doctrine of knowledge ${ }^{\star}$
}

\author{
M. Bunte \\ Westfälische Wilhelms-Universität Münster, \\ 1, Johannisstraße, D-48143, Münster, Germany
}

For citation: Bunte M. The real as problem in Fichte's doctrine of knowledge. Vestnik of Saint Petersburg University. Philosophy and Conflict Studies, 2019, vol. 35, issue 1, pp. 25-31. https://doi.org/ 10.21638/spbu17.2019.102

Fichte describes in his The Characteristics of the Present Age (Grundzüge des gegenwärtigen Zeitalters) a three-stage structure of world history. In the first age of the world the reason stands in instinct and credibility, and therefore the Foundation of the beliefs reached through them, remain hidden from him. This fact, according to Fichte, explains the lack of science in this age. Our age marks the turning point where the rising reason begins. This rise, that is, the liberation of the reason from the form of instinct, is that this age in principle learns the idea of science as a clear understanding of itself. However, this knowledge of his own nature transhistorically this age still do not understand real science, indeed a defining reason, understanding the science is only formally. The new age, that is about to come, will be, according to Fichte, an "epoch of the science of reason" in which philosophy has solved all problems of justification. This will be the very basis for the ongoing systematic progress of science. Despite the undeniable progress that science has made since the time of Fichte this goal has not been achieved to this day. In the essay, I will try to show why this promise of Fichte's "science of knowledge" has not been fulfilled. The answer lies in certain unresolved problems of transcendental philosophy in general and the Fichtian philosophy in particular. Namely, Fichte also failed to completely solve the problem of transcendent schematism, because he did not demonstrate the separation of thought and intuition. In addition, I will indicate a possible solution by surmounting the transcendental schematism.

Keywords: Fichte, philosophy of history, transcendental philosophy, system, schematism.

\section{On the problem of moving from xritique to system in his Characteristics of the Present Age ${ }^{1}$}

In his lectures on The Characteristics of the Present Age (Grundzüge des gegenwärtigen Zeitalters) held for the winter semester of 1804/05, Fichte sums up the spiritual situation of his time as one of "absolute indifference to all truth" [1, S. 11] and as "a state of perfected sinfulness" [1, S. 12]. At first glance this looks as if Fichte is joining the long tradition of lament over the times, which can be traced back to Plato's day or even to the Vedic era of India. However, a brief examination of the concept of history developed by Fichte makes clear that this impression does not do him justice, and that he is not merely bent on discrediting his own age. Rather he aims to grasp the course of history as a process, determined a priori, of the self-unfolding of reason, such that on the basis of this philosophical understanding of history even the deplored state of the present appears as a necessary

* This article was written with the kind support of the Chilean Foundation FONDECYT as part of the research project "The Foundation of Theoretical and Practical Reason", No. 3180686.

${ }^{1}$ Translated from German by Joseph O'Leary.

(c) Санкт-Петербургский государственный университет, 2019 
stage in the evolution of rationality. This process itself obeys the law of Aristotelian dramaturgy, that is, it is divided into five acts in two opposing phases, with a peripateia in the middle, in the third act (cf. $[1, \mathrm{~S} .8])$. Fichte applies this theatrical pattern to the drama of the emergence of perfectible reason, envisioned very much in the manner of Rousseau.

This perfectibility, exemplified both in the phylogenetic and in the ontogenetic series, finds its expression in an overcoming of instinctual nature, stage by stage, as reason comes to itself. The hallmark of this historical process is that it possesses the double stamp of reason in its unity as both theoretical and practical so that Fichte can characterize it as the development of both an increasing determinacy and growing freedom. In the first epoch, the "state of innocence of the human race" [1, S.11], humanity is in a quasi-infantile, purely instinct-dependent state. As the new instinct of reason seeks to free itself from this primitive instinctual state (cf. [1, S.9]), the primordial milieu of self-contained humanity is transformed into a second state in which reason acknowledges the necessity of external submission. However, this epoch of authority still does not fulfill the claim of reason to self-determination. With this, the third epoch, the present epoch for Fichte, takes the stage. Here reason frees itself from the instinct of reason itself (cf. [1, S.9]).

The peculiarity of this transitional epoch is that on the one hand it recognizes the idea of science as a self-penetrating understanding, according to the principle that "nothing is to be accepted as existing and binding except what one understands and conceives clearly" $[1$, p. 21]. But in this recognition of its own nature, scientific thinking remains merely formal and has not yet raised itself "to the reality of science, of truly determining reason" [1, p. 105]. This holds both for its theoretical and its practical claims and is conditioned by the use of the specific liberative instrument of reason, the concept (cf. [1, S.21]). Thus, in the epoch of critique, in which reason wins freedom from heteronomous authority, it does not achieve speculative use of its own most concept, the idea. As a result, science cannot wholly embrace its own nature. Science and its object are not yet understood from the principle of their unity, namely reason itself, as "the only possible existence and life that rests on itself and sustains itself, of which everything that appears as existing and living is but the further modification, definition, transformation, and self-shaping" [1, S.23].

Such a consciousness will be given to reason only in the following fourth "epoch of the science of reason" [1, S.12], the "state of rising justification" [1, S. 12], in which philosophy further determines itself as a real science, in order to return to itself in the fifth "epoch of the art of reason" [1, S. 12] when it enters "the state of perfected justification and healing" $[1, \mathrm{~S} .12]^{2}$. The idea of recovering an initial innocence through the reflected progression of reason, or of humanity's "going back to the point at which it stood at the beginning" [1, S.12], again shows a strong imprint of Rousseau, probably mediated by Kant (cf. [3, S. 117 f.; 4, S. 38]).

On the near side of this utopian telos in the circle of the reflection of reason realizing itself in history, the peripeteia of the third, present epoch testifies witness to Fichte's originality over against Kant and more widely. However, it also points to the central problem of a transcendental philosophy that wants to understand itself systematically, such as Fichtes doctrine of science certainly is. This problem is that of the transition from the formal to the material determination of science as a philosophy of the real.

${ }^{2}$ An overview of the stages can be found in the presentation of the Grundzüge in "Der ganze Fichte" $[2$, S. 252]. 
From the vantage of the pure science of reason or from a philosophy of the real, the whole field of science is completely surveyed, and what each individual science must perform is determined [1, S. 107].

With this, in the Grundzüge, Fichte unmistakably joins Kant's continuation of the great project of the instauratio magna. We find a very similar formulation in the third and penultimate main section of the Doctrine of Method in the Critique of Pure Reason:

Under the government of reason, our insights must never be rhapsodic but must make up a system, in which they alone can support and promote its essential purposes. By a system, I understand the unity of the manifold insights under an idea [5, A 832-B 850; S. 860].

Fichte sees with great lucidity that this promise of a system of science could be fulfilled neither by Kant himself nor in the aftermath of Kant's philosophy, so that the critical path did not lead through the metamorphosis of "a footpath into an army road" [5, A 856 | B 884; S. 879] to "eternal peace in philosophy" (cf. [3, S.411ff.; 6, S. 77 ff.]). The reason for this failure lies, as Fichte again clear-sightedly noted in the Prolegomena to the second 1804 lecture course on the doctrine of science (in the same year as the Grundzüge), in the unresolved residual architectural, that is, ontological problem of Kant's system, in that Kant "had first found the actual difference between the supersensible and the sensuous, and now also brought into his absolute the second uninvestigable quality after its absoluteness, namely that it was the bond of the two worlds" $[7, \text { S. 38 }]^{3}$. Thus Kant, with Fichte, reaches only a postulated actual point of the unity of his system, which culminates in his substrate doctrine. He combines, and so as it coupled the soberly empirical upshot of his philosophy, for which experience is the beginning of all knowledge ${ }^{4}$, with a supersensible, metaphysically unexplicated element, which gives an opening to enthusiasm - Schwärmerei. Here the empirical zeitgeist dialectically turns into its opposite:

In sum, this may well be the spirit of the particular period of our age in which we live: the system for which sober experience alone is valid may be dying out, while against it we see rising to dominance the system of enthusiasm (Schwärmerei) that through pretended speculation will banish experience itself from the area which belongs to it alone, with all the consequences destructive to order that this entails, and in order to punish cruelly those who subscribed to the first system. To counteract this onrush is a futile enterprise, for this is the tendency of the times, which is also reinforced with all its other favored inclinations. In this situation, happy is the sage who raises himself above his age and above all time, for he knows that time is nothing at all, and that higher guidance, through all apparent detours, is quite securely leading our species to its true goals! [1, S. 127]

The "apparent detours" were to turn out to be more extensive than Fichte may have guessed. The eternal peace of the republic of scholars as well as the supremacy of transcendental philosophy or the doctrine of science seems today just as remote as in Fichte's time. In terms of Fichte's historical-philosophical approach, we find ourselves still in the third epoch! Many, perhaps even most, contemporary philosophers would probably explain this by saying that Fichte's ideal historical sketch was just wrong and his claims for

\footnotetext{
${ }^{3}$ WL-1804-II, 4.Vortrag, GA II/8: 60; SW X: $118 \mathrm{f}$.

4 „Daß alle unsere Erkenntnis mit der Erfahrung anfange, daran ist gar kein Zweifel...” [5, B 1, S. 43].
} 
what philosophy could achieve simply presumptuous. But if we consider Fichte's claim to systematicity with regard to the two realms of being - nature and culture - then his ideas do not seem at all far-fetched:

All science that is purely a priori can be completed and its investigations brought to a conclusion, and if only the republic of scholars keeps working on it systematically it will eventually reach this completion. Only the empirical is infinite, whether it be of what is stationary, of nature, in physics, or of what is in flux, the phenomena of the human race, in history. The science of reason, which sifts out all the a priori constituents of physics and perfects them in their particular disciplines and sets them forth in their completed form, then refers physics to experiment and confers on it the art of correctly grasping the meaning of the experiment made, as well as regulative insight into how nature may in each case be further questioned. The same science of reason, abstracts from history the myths about the beginnings of the human race, as belonging to metaphysics, and confers a determinate concept of how history ought properly to ask and what belongs to it, as well as a logic of historical truth: and so even in this infinite realm secure progress according to a rule steps into the place of a random rummaging about [1, S. $107 \mathrm{f}$.].

What makes this passage so instructive is the way Fichte offers suggestions about the relationship of experience and rational science, seeking to mediate between them along Kantian lines via the regulative a priori, while skipping over the real question, namely the possibility of the constitution of coherence by the regulative. This avoidance of the actual question of epistemology - how can the determinable be conceived of as itself determinate, if it is determinable in view of a determinate - is shared by Fichte and Kant. But in contrast to Kant, Fichte takes a further decisive step, in that he marks the leap as such, by raising the comprehension of non-comprehension in the form of the inherent boundary determination of rational science to the highest point of its reflection.

But as far as comprehension itself is concerned, the science of reason establishes as a principle that everything, and even non-comprehension, must be understood as the limit of comprehension and the only possible pledge that comprehension is exhausted; and that indeed in every time, and as the sole bearer of the time, one may encounter such a non-comprehended, something comprehended only as not comprehend - yet never anything absolutely incomprehensible $[1$, S. 113].

Fichte's inoculation of incomprehensibility in the system of transcendental philosophy as a noetic transcendence immanent in knowing does seem consequent, but comes with the cost that the doctrine of science as a teaching of unity and splitting, that is, as the theoretical praxis of a logic of grounding and determination, must in consequence expound its highest point as a logic of speculation, but cannot return without a break from this to the particular in the course of the speculative logic of concretion. This is evidenced in the way Fichte, in discussing the deductiveness of the particular, mostly remains remarkably assertoric, without being very convincing (cf. [1, S. 132]).

However, it would be quite misguided to lay this charge only against Fichte himself, since it bears on a grave problem concerning the matter of first philosophy, a problem that has still not been sufficiently clarified. If one looks at the state of the current debates, one observes that these generally do not begin to approach the level of Fichte's grasp of the problem. Both Fichte and Kant engage the problem of given determinacy in a similar way, namely through a theory of schematization: 
Knowledge is, as we have said, existence, expression, the perfect image of divine power. It is therefore for itself: Knowledge becomes self-consciousness; and it is for itself, in this selfconsciousness, its own power, freedom and effectiveness, resting on itself, because it is indeed the image of divine power; all this as knowledge, and therefore as evolving through all eternity toward higher inner lucidity of knowing. The knowing refers to a determined object of knowledge from which it takes its departure; this evidently appears as a determinate something, which could also be different, since it is, and yet in its primal ground is not comprehended, but knowing must seek to comprehend it through all eternity, thus developing its own inner power: and it is with this progressive development that time first enters in [1, S. $130 \mathrm{f}$.].

Fichte's transcendental theory of representation and image differs from Kant's in one essential point: whereas Kant's transcendental schematism is a subsumption-schema that is logically subsequent to a separation of the cognitive faculties, Fichte's schematism is a schema of production or projection that comes before any cognitive achievement. However, Fichte's schematism, too, fails to escape the difficulty of all doctrines of schematism. Just as Kant sets up the mutually determining relationship of intuition and concept at the level of possibility, as determining their relation before the actual schematization of the concept through the application of the logical function to the pure form of the inner intuition, so Fichte, as if mirroring him, presupposes the possibility of their separability at the ground of the unity of knowledge. So if Kant can hardly give a plausible of how thought and intuition are bound together, it is just as difficult for Fichte to demonstrate their separation.

What does this mean for the future of transcendental philosophy? Certainly, the most obvious thing would be to bid farewell to the schematism altogether and to withdraw entirely to the standpoint of dialectic, either with Hegel's heautological dialectic that obtains determinacy by the principle of sublation or with Wolfgang Cramer's heterothetic one, which seeks knowledge of determinacy from the principle of positivity. However, this obvious strategy does not gain traction for two reasons: First, it would at least be necessary, with Hegel, to revise Fichte's insight into the incomprehensibility of the Absolute, and secondly - a point that weighs heavier in systematic implications - Hegel's principle of selfconceiving self-grasp always presupposes its claim to validity in its making-itself-valid. That, from a critical point of view, is at best merely thetical, and in the worst case even circular. Likewise, Cramer's transcendental ontology founders in the last instance - or the first, depending on one's perspective - on the problem of the ontological determinateness of its problematic ground. Of course, the same can also be said of Nicolai Hartmann's transcendental-realistic standpoint, although Hartmann can certainly be given credit for integrating the problem into his relinquishment of the system in favour of systematics, even though his proposed solution in the form of his categorial analysis remains completely inadequate in terms of transcendental philosophy.

The problem of the third epoch, the transition from formal to material use of the idea within the framework of the science of reason, is thus still not adequately elucidated. This takes nothing of its topicality and explosiveness from Fichte's claim or from Kant's. For this reason alone the debate with them should unreservedly be conducted from a systematic perspective and must just as a topic of philological or historical inquiry. However, this also means that it must be possible to give a systematically convincing answer to the question of the transition. In order to achieve this, it would be necessary to explicate the unity-creating relationship between heautology and heterothetics in such a way that it 
can identify the possibility of grounding and ordering validity — and thus the possibility of logical inference - on the basis of a systematic apriori. However, success in this first requires a coherent, that is, a schematism-free theory of concept and intuition, within the framework of a critical science of knowledge embracing them both, in which the transition from transcendental philosophy to a general theory of system and structure is laid out. Thereby the long-awaited transition to the fourth epoch may come about.

\section{References}

1. Fichte, J. G. (1846), “Grundzüge des gegenwärtigen Zeitalters”, in Fichtes Werke, ed. Fichte, I. H., Bd. 7, Veit und Comp., Berlin, Prussia, S. 3-256.

2. Oesterreich, P. and Traub, H. (2006), Der ganze Fichte. Die populäre, wissenschaftliche und metaphilosophische Erschließung der Welt, Kohlhammer, Stuttgart, Germany.

3. Kant, I. (1923), Kant's gesammelte Schriften, ed. Preußische Akademie der Wissenschaften, Bd. 8, Walter de Gruyter, Berlin, Germany.

4. Kant, I. (1999), „Mutmaßlicher Anfang der Menschengeschichte”, in Kant, I., “Was ist Aufklärung?”, Ausgewählte kleine Schriften, Meiner, Hamburg, Germany, S. 28-44.

5. Kant, I. (1998), Kritik der reinen Vernunft, Meiner, Hamburg, Germany.

6. Kant, I. (1999), "Verkündigung des nahen Abschlusses eines Traktates zum ewigen Frieden in der Philosophie", in Kant, I., "Was ist Aufklärung?”Ausgewählte kleine Schriften, Meiner, Hamburg, Germany, S. 77-87.

7. Fichte, J. G. (1986), Die Wissenschaftslehre. Zweiter Vortrag im Jahre 1804, Meiner, Hamburg, Germany.

Received: March 15, 2018

Accepted: October 3, 2018

Author's information:

Martin Bunte — PhD, Assistant Professor; martinbunte@yahoo.de

\section{Реальное как проблема в учении о знании И. Г. Фихте}

\section{М. Бунте}

Вестфальский университет им. Вильгельма,

Федеративная Республика Германия, Д-48143, Мюнстер, Юханштрассе, 1

Для цитирования: Бунте М. Реальное как проблема в учении о знании И.Г.Фихте // Вестник Санкт-Петербургского университета. Философия и конфликтология. 2019. Т. 35. Вып. 1. C. 25-31. https://doi.org/10.21638/spbu17.2019.102 (In English)

Фихте в работе «Основные черты современной эпохи» («Grundzüge des gegenwärtigen Zeitalters») описывает трехступенчатую структуру мировой истории. В первую эру мировой истории разум выступает в виде инстинкта и авторитета, и поэтому основания убеждений, достигнутых с их помощью, остаются скрытыми от него самого. Это обстоятельство, по Фихте, объясняет отсутствие в ту эру науки. Наш век, в его изложении, представляет собой поворотный момент, в который начинается подъем разума. Этот подъем, т. е. освобождение разума от формы инстинкта, заключается в том, что данная эпоха в принципе познает идею науки как ясного себе понимания. Однако в этом познании своей собственной природы эта трансисторическая эпоха все же не постигает реальную науку, действительно определяющий разум, понимая науку лишь формально. Новая эра, которая вскоре должна наступить, будет, по мнению Фихте, 
«эпохой науки разума», в которую философия решит все проблемы обоснования. Это станет основой для поступательного систематического прогресса науки. Несмотря на бесспорный прогресс, совершенный наукой со времен Фихте, эта цель не достигнута и по сей день. В статье автор стремится показать, почему «наука знания» до сих пор не исполнила данные Фихте обещания. Ответ на этот вопрос кроется в нерешенности некоторых проблем трансцендентальной философии в целом и философии Фихте в частности. А именно: Фихте не смог окончательно решить проблему трансцендентального схематизма, поскольку не продемонстрировал разделение мышления и созерцания. Кроме того, в статье указывается на возможное решение этих проблем, которое заключается в преодолении трансцендентального схематизма.

Ключевые слова: Фихте, философия истории, трансцендентальная философия, система, схематизм.

Статья поступила в редакцию 15 марта 2018 г.; рекомендована в печать 3 октября 2018 г.

Контактная информация:

Бунте Мартин — PhD, ассистент; martinbunte@yahoo.de 